\title{
Prólogo a la cuarta edición de la Historia económica y social - Tomo primero ${ }^{\mathrm{A}}$
}

Este libro hace parte de la iniciación de una carrera universitaria. Fue una especie de manifiesto personal como muchas obras de esos años que expresaba una fe un poco ingenua y arrogante en las virtudes de la discusión académica. La universidad se ofrecía como un refugio para la discusión de los verdaderos problemas del país. Cada cuestión sometida a la reflexión iría ampliándose y encontrando una claridad meridiana. Incorporar estos problemas a la docencia crearía una disciplina y un compromiso auténtico con el saber en las nuevas generaciones. Hoy, después de diez años, la fe se ha atemperado y la arrogancia ha desaparecido. A las grandes cuestiones ha sucedido la preocupación cotidiana y angustiosa de la supervivencia misma de la universidad amenazada por el mercantilismo, por las soluciones burocráticas, por la apología del acto puro y por un escepticismo que se va ahondando cada día.

El libro quería hacer parte de un debate sobre las orientaciones de las investigaciones en la universidad. ¿Debía aceptarse, sin más, las confusiones de un debate pretendidamente teórico que tenía por objeto identificar emocionalmente a los abanderados de una lucha ideológica o debía ahondarse en el estudio, mucho más modesto, de la realidad nacional? Había quienes reprochaban a los historiadores su excesiva atención a los detalles, su empirismo, y no forjar un instrumento adecuado para definir una posición "correcta" en la lucha ideológica. No se trataba — según ellos — de cons-

A Se trata del prólogo a una nueva edición realizada en 1983 por Tercer Mundo Editores de la Historia Económica y Social de Colombia, 1537-1719, aparecida por primera vez diez años antes, al regreso de G. Colmenares de París, en donde había presentado este trabajo como tesis de Tercer Ciclo, para graduarse como Doctor en Historia. En el texto, el historiador expresa cierto escepticismo sobre los poderes del conocimiento histórico para cambiar la sociedad, y muestra que ciertas ilusiones exageradas sobre el poder de la enseñanza han ido moderándose, aunque tal moderación no dio lugar en el historiador a ninguna forma de cinismo. Expresa así mismo la consciencia que tiene del hecho inevitable del paso del tiempo sobre su propia obra de diez años atrás. Al final del corto texto Germán Colmenares vuelve a expresar su inquietud por la suerte de la universidad pública colombiana y hace una afirmación que seguimos compartiendo - la importancia de la investigación en la vida académica - y otra afirmación más que mantiene su permanencia y que resulta de una urgencia innegable, la defensa de la universidad pública. En palabras de Colmenares "una universidad que se desmorona en medio del más universal escepticismo", y no solo por los ataques de la "política educativa oficial", pues hay muchos otros factores por considerar cuando se quiera tener un diagnóstico que no se agote en la retórica ritual de nosotros los universitarios. Como se sabe, la pregunta por la supervivencia de lo que Colmenares llamaba "una universidad liberal", es una constante en la obra del historiador, y corre paralela a su crítica de la violencia universitaria y a sus repetidos señalamientos de la forma como el Estado se iba desentendiendo de una universidad pública que cada vez le interesaba menos, a la par que las ideologías tecnocráticas sobre la educación se iban imponiendo, lo que es fácil de constatar comparando el perfil cultural de los ministros de educación del periodo 1930-1980, incluidos los conservadores, con lo que ha ocurrido posteriormente, bajo el dominio de la ideología designada bajo el mote de "economía de la educación". 
truir una historia o una interpretación buena o mala sino de saber a quién iba a servir como instrumento teórico. Una dudosa epistemología, según la cual la objetividad se alcanzaba en virtud de una posición de clase, era un artículo de fe, muy confusamente expuesto. De todo esto, infortunadamente, solo ha quedado la chocante propensión a usar, a troche y moche, la expresión galicada "a nivel de".

Hoy existe más tolerancia hacia los estudios históricos. Con el tiempo ha ido definiéndose el profesionalismo de una actividad académica y el sentido de sus limitaciones. La vieja retórica ya disimula muy mal la mala fe e ignorancia. Se ha agudizado la conciencia de que la discusión confusa genera intolerancia y desemboca en el escepticismo y en formas inaceptables del irracionalismo. Estos, como síntoma de una crisis intelectual profunda, sólo sirven para justificar el acto puro, la acción por la acción, que destruyen cualquier ámbito de discusión.

Obviamente, me separan de este libro diez años y la conciencia de que los debates en que quería inscribirse están moribundos. Pero sigo creyendo, como entonces, en la necesidad de la investigación para hacer posible — y soportable - una universidad que se desmorona en medio del más universal escepticismo. 